\title{
Testing of the fleet of the vehicles with diesel engines fed by BIOXDIESEL fuel
}

The paper presents results of testing of the fleet of the parcel delivery vehicles, equipped with the Diesel engines fed by biofuel BIOXDIESEL, manufactured on the way of the ethanol esterification process of the waste vegetable and animal fats, with the addition of the standard diesel fuel and pure ethanol. The comparison results of the vehicles test bed on the beginning of the testing and at the end of the testing, when vehicles were fueled with standard diesel and testing biofuel. The results of the testing at non-stationary states are also presented. The paper presents also results of the drivers evaluation of the performance of the vehicles based on the questionnaire. Presented results show that the BIOXDIESEL fuel is fully replaceable to the standard diesel fuel.

Key words: biodiesel, fatty acid ethyl esters, compression ignition engines

\section{Introduction}

According to Polish and European law, it is allowed to add to the fuel specified for Diesel engines, up to $7 \%$ of biocomponents, according to calorific value. Such biocomponents currently are only the fatty acid methyl esters (FAME). Current standards and legal acts regarding quality of biofuels, as well as from tax point of view, require only FAME.

From the other hand, the other type of biocomponents, especially fatty acid ethyl esters FAEE, manufactured from waste animal and vegetable fats, and fully renewable bioetanol, are at least as valuable from engine performance, environmental aspects, and quality point of view.

Currently methanol, which is used as a feedstock to produce FAME is obtained from fossil resources. It is also worth to mention, that methanol and its vapors are toxic.

Replacement of methanol with ethanol allows production of FAEE, which chemical and physical properties are beneficial from fuel point of view. Also the products of combustion of FAEE are less harmful to the environment in comparison with FAME [1].

According to the current Polish law, the selected fleet of the vehicles is defined as a group of at least 4 vehicles, agriculture tractors or other off-highway machines or group of locomotives or ships, equipped with the engines which can be fueled with liquid biofuel. The vehicles should be used by the same user. The law allows, that the properties of the fuel can be different than stated in standards or other legal requirements.

\section{Description of the testing fuel}

For testing of the fleet vehicles the experimental fuel BIOXDIESEL has been used. This new fuel is a blend of the Fatty Acid Ethyl Esters (FAEE) with addition of standard Diesel fuel and bioethanol. There are also additives, which are improving cold flow properties of the fuel.

Due to lack of the standards in Poland and in Europe regarding FAEE, the physical and chemical properties of the BIOXDIESEL fuel are compared with the PN-EN 590:2013 standard, which describes diesel fuel quality parameters. FAEE quality is also compared with the PN-EN 14214 standard, which regards FAME only.
In the USA, Brasil and India the methyl or ethyl esters are not distinguished in the standards, which are describing fuel parameters. The biofuel just has to meet standard requirements, eg. ASTM D6751 in the USA, ANP 42 in Brasil or IS15607:2005 in India.

Table 1 presents selected quality parameters of the BIOXDIESEL fuel (results obtained by the authors) compared with PN-EN 590 and PN-EN 14214+A1.

Table 1 . Selected quality parameters of the BIOXDIESEL fuel compared with standards for Diesel fuel and for FAME

\begin{tabular}{|c|c|c|c|c|c|c|}
\hline \multirow[t]{2}{*}{ Parameter } & \multirow[t]{2}{*}{ Units } & \multirow{2}{*}{$\begin{array}{l}\text { Properties of } \\
\text { BIOXDIESEL } \\
\text { fuel }\end{array}$} & \multicolumn{2}{|c|}{$\begin{array}{c}\text { PN-EN 590:2013 } \\
\text { requirement }\end{array}$} & \multicolumn{2}{|c|}{$\begin{array}{c}\text { PN-EN } \\
14214+\mathrm{A} 1 \\
\text { requirement }\end{array}$} \\
\hline & & & $\min$ & $\max$ & $\min$ & $\max$ \\
\hline $\begin{array}{l}\text { Cold } \\
\text { Filter } \\
\text { Plugging } \\
\text { Point }\end{array}$ & {$\left[{ }^{\circ} \mathrm{C}\right]$} & -17 & \multicolumn{2}{|c|}{$\begin{array}{c}\text { Season } \\
\text { dependent } \\
\text { eg. intermediate } \\
-10^{\circ} \mathrm{C}\end{array}$} & \multicolumn{2}{|c|}{$\begin{array}{c}\text { Season } \\
\text { dependent eg. } \\
\text { intermediate } \\
-10^{\circ} \mathrm{C}\end{array}$} \\
\hline $\begin{array}{l}\text { Cetane } \\
\text { number }\end{array}$ & & 51.9 & 51 & & 51 & \\
\hline $\begin{array}{l}\text { Density at } \\
15^{\circ} \mathrm{C}\end{array}$ & $\mathrm{kg} / \mathrm{m}^{3}$ & 868 & 820 & 845 & 860 & 900 \\
\hline $\begin{array}{l}\text { Flash } \\
\text { point }\end{array}$ & ${ }^{\circ} \mathrm{C}$ & 24 & 55 & & 101 & \\
\hline $\begin{array}{l}\text { Viscosity } \\
\text { at } 40^{\circ} \mathrm{C}\end{array}$ & & 2.33 & 2 & 4.5 & 3.5 & 5 \\
\hline $\begin{array}{l}\text { Calorific } \\
\text { value }\end{array}$ & $\mathrm{MJ} / \mathrm{kg}$ & 38.5 & \multicolumn{2}{|c|}{42.8} & \multicolumn{2}{|c|}{38} \\
\hline
\end{tabular}

The fatty acid ethyl esters were obtained on the way of transesterification of the waste animal (pork and poultry) fats, waste vegetable fats, eg. used frying oils and small addition of fresh rapeseed oil with bioethanol in the presence of alkali catalyst $(\mathrm{KOH})$. The selection of feedstock for production of FAEE used for BIOXDIESEL fuel is described in [6].

The application of waste animal fats as a feedstock for biodiesel production is a subject of an intensive research also around the world, eg. [2, 3].

The BIOXDIESEL used for feeding the engines of the fleet vehicles used for the testing is a blend mate of about $70 \%$ of biocomponents (FAEE and bioethanol) and about $30 \%$ of diesel fuel with additives. 


\section{Description of the fleet vehicles used for testing}

The fleet used for testing consisted of 15 parcel delivery vehicles. The vehicles have been used on different duty cycles: 5 vehicles were operated in the cities, 5 in long distances and 5 vehicles in the mixed duty cycles. Table 2 describes the fleet vehicles and their engines.

Table 2. Description of vehicles and engines used for fleet testing

\begin{tabular}{|c|c|c|c|c|}
\hline $\begin{array}{c}\text { Make, } \\
\text { model }\end{array}$ & $\begin{array}{c}\text { Year of } \\
\text { build }\end{array}$ & $\begin{array}{c}\text { Engine } \\
\text { displacement } \\
{[\mathrm{ccm}], \text { no of }} \\
\text { cylinders }\end{array}$ & $\begin{array}{c}\text { Max engine } \\
\text { power } \\
{[\mathrm{BHP}]}\end{array}$ & $\begin{array}{c}\text { Max engine } \\
\text { torque } \\
{[\mathrm{Nm}]}\end{array}$ \\
\hline $\begin{array}{l}\text { Citroen } \\
\text { Jumper }\end{array}$ & 2011 & $2200,4 \mathrm{cyl}$ & 100 & 250 \\
\hline $\begin{array}{l}\text { Citroen } \\
\text { Berlingo }\end{array}$ & 2011 & $1560,4 \mathrm{cyl}$ & 75 & 185 \\
\hline
\end{tabular}

\section{Testing procedures of the fleet vehicles fed with}

\section{BIOXDIESEL fuel}

The vehicles have been thoroughly examined before start of the testing.

On the day of fuel replacement, the engine performance was evaluated on the vehicle test bed, when vehicles were fed with standard Diesel fuel. Also the engine performance in non-stationary condition was measured according to the procedure described in [1] and [5].

Just before filling the vehicles' fuel tanks with BIOXDIESEL fuel the oil, oil filters and fuel filters were replaced with the new ones.

Then the vehicles were tested with in non-stationary conditions according to [1] and [5] again with the experimenttal fuel. Also the vehicles engine performance was tested on the vehicle test bed.

In the middle of the test the vehicles engine performance was measured in non-stationary states.

Then at the end of the test vehicles were tested in nonstationary conditions and on the vehicle test bed with BIOXDIESEL fuel and after replacement with standard Diesel fuel.

\subsection{Description of the testing in non-stationary conditions}

The testing procedure is described in details in [1] and [5]. The testing in non-stationary conditions consists the set of rapid acceleration and deceleration of the engine from idling to maximal speed, back to idling. The engine is loaded by the moment of inertia of moveable parts of the engine.

The cyclodynes are the curves drawn on the engine torque - engine revolution plane. It is possible to draw cyclodynes in the angular acceleration - engine crankshaft rotational velocity, when the information about polar moment of inertia of the engine is not known. For comparison purposes it is possible to use the angular acceleration - engine speed plane.

The cyclodynes remain loops, which positive part is drawn when accelerating and negative part during deceleration. The area of the positive part of cyclodynes is related to the energy generated by the engine during acceleration (depend calorific value of the fuel and efficiency of burning of the fuel), while negative part of the cyclodyne depends on overall condition engine and quality of lubrication oil in the engine.

\subsection{Description of the on the vehicle test bed}

The performance of the vehicles was evaluated in cooperation of ECU-PROJECT company, on the 4DW test bed manufactured by Dynoproject. This test bed is able to test the vehicles with maximum power of 1000 BHP and maximum torque of $1000 \mathrm{Nm}$ and results are corrected according to DIN 70020.

The torque and power vs. engine crankshaft revolution graphs have been obtained for each of the vehicles.

\section{Description of the vehicles performance evaluation based on the questionnaire}

The drivers of the vehicles were obliged to fill in the questionnaire describing their subjective opinion about vehicle's performance. They had to provide their opinion about following vehicles' performances:

- Traction of the vehicles (acceleration of the vehicles and driving with load);

- Engine performance (cold start, hot start, engine noise and exhaust evaluation);

- Vehicle's tachometer at the beginning of each drive, date and type of the duty (urban, extra urban, mixed);

- Information about amount of the fuel filled;

- Information about the service or repair activities.

The engine and vehicle's performance was evaluated based on the 3 grades: low, middle and high.

\section{Results}

The results consisted a set of data obtained on the vehicle test bed and also results of the data coming from the testing in non-stationary conditions.

\subsection{Results of the vehicles performance measured on the vehicle test bed}

Table 3 presents results of measurement of peak engine power and peak engine torque measured on the test bed for selected vehicles at the end of the test. It is noticeable, that the maximum power for Berlingo vehicles is about $8 \%$ lower when fueling with BIOXDIESEL fuel in comparison with standard diesel fuel. Similar trend can be observed for torque measurement. This can be explained with the fact, that the calorific value of BIOXDIESEL fuel is $10 \%$ lower than standard Diesel fuel.

Table 3. Examples of results of the vehicle test bed obtained for selected Citroen Berlingo vehicles, obtained at the end of the test

\begin{tabular}{|c|c|c|c|c|}
\cline { 2 - 5 } \multicolumn{1}{c|}{} & \multicolumn{2}{c|}{ Standard diesel fuel } & \multicolumn{2}{c|}{ BIOXDIESEL fuel } \\
\cline { 2 - 5 } \multicolumn{1}{c|}{} & Max Power & Max torque & Max Power & Max torque \\
\cline { 2 - 5 } \multicolumn{1}{c|}{} & BHP(RPM) & $\mathrm{Nm}$ & BHP(RPM) & $\mathrm{Nm}$ \\
\hline Berlingo_1 & $76(3135)$ & $187.7(2256)$ & $69.6(3030)$ & $173.3(2200)$ \\
\hline Berlingo_2 & $76.6(3096)$ & $186.9(2255)$ & $68.2(2993)$ & $170.6(2213)$ \\
\hline Berlingo_3 & $77.9(3067)$ & $191.8(2181)$ & $68.8(3058)$ & $169.9(2173)$ \\
\hline Berlingo_4 & $76.8(3080)$ & $188.5(2222)$ & $68.4(3045)$ & $167.1(2194)$ \\
\hline Berlingo_5 & $74.9(3112)$ & $180(2253)$ & $66.9(3035)$ & $160.8(2243)$ \\
\hline Berlingo_6 & $76.3(3087)$ & $188.4(1964)$ & $68.7(3033)$ & $166.3(2266)$ \\
\hline Berlingo_7 & $73(3054)$ & $179.7(1981)$ & $66.3(3157)$ & $164.5(2229)$ \\
\hline Berlingo_8 & $75.3(3061)$ & $187.8(2205)$ & $69(3012)$ & $172.6(2172)$ \\
\hline Average & $75.6(3204)$ & $185.6(2177)$ & $68.0(3041)$ & $167.8(2213)$ \\
\hline
\end{tabular}

In Table 4 results of measurement of the peak power and torque measured on the test bed for are presented. It is 
noticeable, that the maximum power for Jumper vehicles is about $7 \%$ lower when fueling with BIOXDIESEL fuel in comparison with standard diesel fuel. Similar trend can be observed for torque measurement, the torque drop when fueling with experimental fuel is about $8 \%$ lower in comparison with standard Diesel fuel, even though the calorific value of BIOXDIESEL is lower by $10 \%$ than Diesel fuel.

Table 4. Examples of results of the vehicle test bed obtained for selected Citroen Jumper vehicles, obtained at the end of the test

\begin{tabular}{|c|c|c|c|c|}
\cline { 2 - 5 } \multicolumn{1}{c|}{} & \multicolumn{2}{c|}{1 ON } & \multicolumn{2}{c|}{ 2 BIOXDIESEL } \\
\cline { 2 - 5 } \multicolumn{1}{c|}{} & Max Power & Max torque & Max Power & Max torque \\
\cline { 2 - 5 } \multicolumn{1}{c|}{} & BHP(RPM) & Nm & BHP(RPM) & Nm \\
\hline Jumper_1 & $116.5(3146)$ & $279.4(2709)$ & $105.4(3350)$ & $244.6(2733)$ \\
\hline Jumper_2 & $113.5(3050)$ & $282(2627)$ & $102.7(3142)$ & $248.9(2659)$ \\
\hline Jumper_3 & $115.6(3014)$ & $283.5(2691)$ & $109.3(3000)$ & $270.5(2618)$ \\
\hline Jumper_4 & $109.8(3208)$ & $266.8(2638)$ & $105.1(3171)$ & $259.3(2607)$ \\
\hline Jumper_5 & $116.7(3045)$ & $285.5(2666)$ & $108.8(3252)$ & $259.9(2725)$ \\
\hline Average & $114.42(3092.6)$ & $279.44(2666.2)$ & $106.26(3183)$ & $256.64(2668.4)$ \\
\hline
\end{tabular}

\subsection{Results of the vehicles performance measured in non-stationary conditions}

Due to shorter measurement procedure the testing in the non-stationary condition took place also in the middle of the long term test.

Figure 1 shows examples of cyclodynes obtained for one of Citroen Berlingo vehicles in the beginning of the test (start day), while figure 2 shows the results of the measurement obtained at the end of the test.
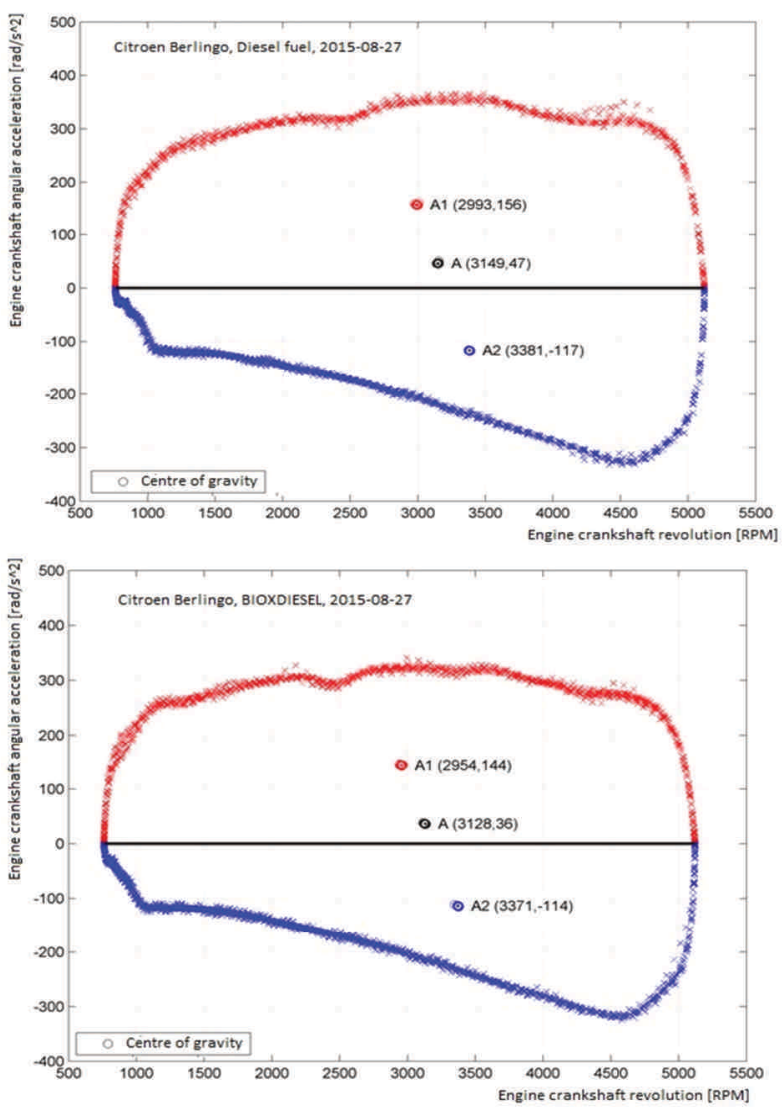

Fig. 1. Results of the testing in non-stationary conditions, start day of the testing; top - standard Diesel fuel, bottom - BIOXDIESEL fuel
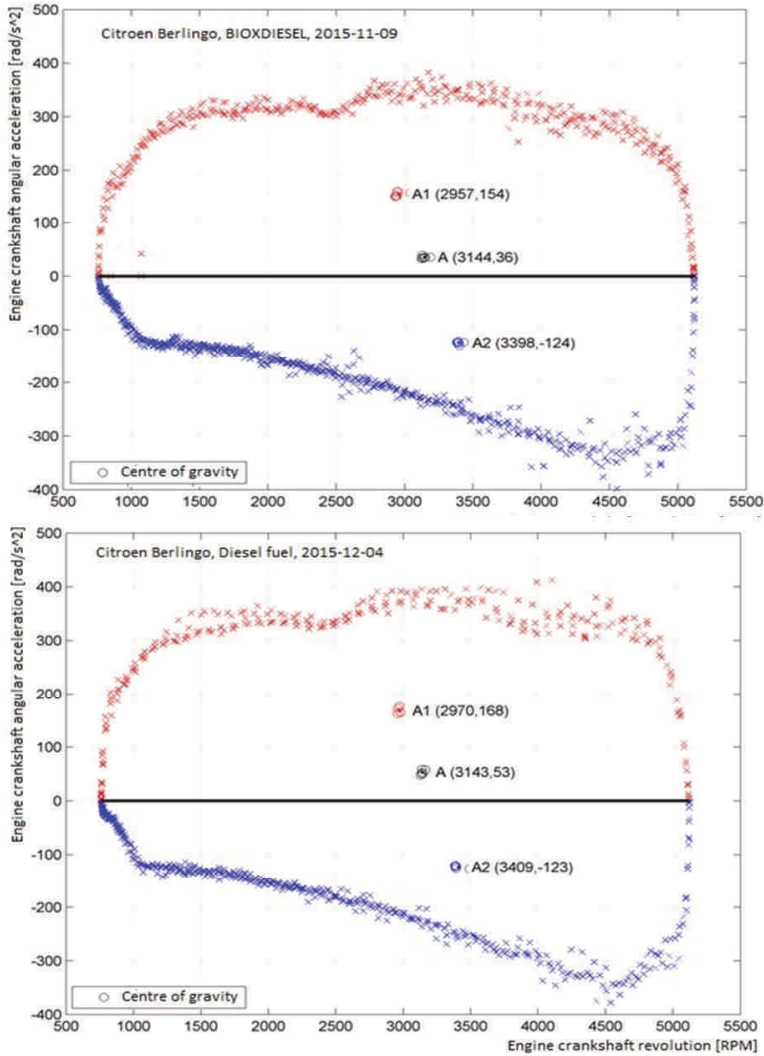

Fig. 2. Results of the testing in non-stationary conditions, end of the testing; top - BIOXDIESEL fuel, bottom - standard Diesel fuel

The outcome of the test in non-stationary condition is the value of the area of the positive part of the cyclodyne loop. The area is proportional to energy conversion of the fuel. Tables 5 and 6 present the area of the cyclodynes obtained at different stages of the test for Berlingo and Jumper vehicles. One can notice, that similarly to the results of the vehicle test bed measurements, the performance of the vehicles was about $8 \%$ lower when using the BIOXDIESEL fuel than standard diesel fuel.

Table 5. Results of the testing the group of Citroen Berlingo vehicles in non-stationary conditions - area of cyclodynes

\begin{tabular}{|c|c|c|c|c|c|}
\hline \multirow{2}{*}{ Vehicle } & 1 ON & 2 BIOXDIESEL & 3 BIOXDIESEL & 4 BIOXDIESEL & 5 ON \\
\cline { 2 - 6 } & $\mathrm{P}_{1}$ & $\mathrm{P}_{1}$ & $\mathrm{P}_{1}$ & $\mathrm{P}_{1}$ & $\mathrm{P}_{1}$ \\
\hline & {$\left[\mathrm{rad} / \mathrm{s}^{2}\right]$} & $\begin{array}{c}{\left[\mathrm{rad} / \mathrm{s}^{2}\right]} \\
{[1 / \mathrm{min}]}\end{array}$ & $\begin{array}{c}{\left[\mathrm{rad} / \mathrm{s}^{2}\right]} \\
{[1 / \mathrm{min}]}\end{array}$ & $\begin{array}{c}{\left[\mathrm{rad} / \mathrm{s}^{2}\right]} \\
{[1 / \mathrm{min}]}\end{array}$ & $\begin{array}{c}{\left[\mathrm{rad} / \mathrm{s}^{2}\right]} \\
{[1 / \mathrm{min}]}\end{array}$ \\
\hline Berlingo_1 & 1316313 & 1213310 & - & 1274083 & 1418216 \\
\hline Berlingo_2 & 1280899 & - & - & 1251420 & 1391665 \\
\hline Berlingo_3 & 1351733 & 1265174 & 0 & 1255458 & 1341255 \\
\hline Berlingo_4 & 1307915 & 1237558 & 1286056 & 1270063 & 1376368 \\
\hline Berlingo_5 & 1316467 & 1222883 & 1215428 & 341941 & 1462068 \\
\hline Berlingo_6 & 1328186 & - & - & 1189034 & 1346919 \\
\hline Berlingo_7 & 1302171 & 1182546 & - & - & - \\
\hline Berlingo_8 & 1338380 & 1226060 & 1267457 & 1300205 & 1368112 \\
\hline Berlingo_9 & - & - & 1270898 & 1286918 & 1387675 \\
\hline Average & 1317758 & 1224588 & 1259959 & 1271140 & 1386535 \\
\hline
\end{tabular}


Table 6. Results of the testing the group of Citroen Jumper vehicles in non-stationary conditions - area of cyclodynes

\begin{tabular}{|c|c|c|c|c|c|}
\hline \multirow{2}{*}{ Vehicle } & 1 ON & 2 BIOXDIESEL & 3 BIOXDIESEL & 4 BIOXDIESEL & 5 ON \\
\cline { 2 - 6 } & $\mathrm{P}_{1}$ & $\mathrm{P}_{1}$ & $\mathrm{P}_{1}$ & $\mathrm{P}_{1}$ & $\mathrm{P}_{1}$ \\
\cline { 2 - 6 } & $\begin{array}{c}{\left[\mathrm{rad} / \mathrm{s}^{2}\right]} \\
{[1 / \mathrm{min}]}\end{array}$ & $\begin{array}{c}{\left[\mathrm{rad} / \mathrm{s}^{2}\right]} \\
{[1 / \mathrm{min}]}\end{array}$ & $\begin{array}{c}{\left[\mathrm{rad} / \mathrm{s}^{2}\right]} \\
{[1 / \mathrm{min}]}\end{array}$ & $\begin{array}{c}{\left[\mathrm{rad} / \mathrm{s}^{2}\right]} \\
{[1 / \mathrm{min}]}\end{array}$ & $\begin{array}{c}{\left[\mathrm{rad} / \mathrm{s}^{2}\right]} \\
{[1 / \mathrm{min}]}\end{array}$ \\
\hline Jumper_ & 1214621 & 1163422 & 1241925 & 1349096 & 1340930 \\
\hline Jumper_2 & 1357113 & 1138616 & 1459679 & 1391904 & 1509587 \\
\hline Jumper_3 & 1261361 & 1183280 & 1228581 & 1315499 & 1263977 \\
\hline Jumper_4 & 1336754 & 1246477 & 1303827 & 1365905 & 1377638 \\
\hline Average & 1292462 & 1182949 & 1308503 & 1355601 & 1373033 \\
\hline
\end{tabular}

\subsection{Description of the vehicles performance evaluation}

\section{based on the questionnaire}

The numerical values describing maximal engine power or maximal engine torque are not giving the full image of the vehicle performance in everyday operation. It was also necessary to collect the opinions of the drivers about driving the vehicles fueled with standard and experimental fuel.

In order to make the subjective opinions comparable the drivers had to evaluate the vehicle's performance on the base of the questionnaire:

- Traction of the vehicles (acceleration of the vehicles and driving with load);

- Engine performance (cold start, hot start, engine noise and exhaust evaluation);

Above questions were evaluated in three grades: low, middle and high.

The questions below were additional, which helped analyzing the data:

- Vehicle's tachometer at the beginning of each journey, date and type of the duty (urban, extra urban, mixed);

- Information about amount of the fuel filled;

- Information about the service or repair activities.

Assuming, that the 'law' value is scored by 0 points, 'medium' as 50 points and 'high' as 100 points, the results of the evaluation for the group of Citroen Berlingo are presented in Table 7.

Table 7. Results of drivers' evaluation of Citroen Berlingo when fuelling with BIOXDIESEL (averaged)

\begin{tabular}{|c|c|c|c|c|c|c|}
\hline Vehicle & $\begin{array}{l}\text { Accelera- } \\
\text { tion }\end{array}$ & $\begin{array}{l}\text { Drive } \\
\text { with } \\
\text { load }\end{array}$ & $\begin{array}{l}\text { Cold start } \\
\text { of the } \\
\text { engine }\end{array}$ & $\begin{array}{l}\text { Hot start } \\
\text { of the } \\
\text { engine }\end{array}$ & Noise & Exhaust \\
\hline Berlingo_1 & $100 \%$ & $100 \%$ & $100 \%$ & $100 \%$ & $100 \%$ & $100 \%$ \\
\hline Berlingo_2 & $100 \%$ & $100 \%$ & $100 \%$ & $100 \%$ & $100 \%$ & $100 \%$ \\
\hline Berlingo_3 & $50 \%$ & $50 \%$ & $50 \%$ & $50 \%$ & $50 \%$ & $50 \%$ \\
\hline Berlingo_4 & $100 \%$ & $100 \%$ & $94 \%$ & $100 \%$ & $98 \%$ & $97 \%$ \\
\hline Berlingo_5 & $50 \%$ & $100 \%$ & $100 \%$ & $100 \%$ & $50 \%$ & $48 \%$ \\
\hline Berlingo_6 & $100 \%$ & $99 \%$ & $100 \%$ & $100 \%$ & $100 \%$ & $42 \%$ \\
\hline Berlingo_7 & $51 \%$ & $52 \%$ & $90 \%$ & $100 \%$ & $100 \%$ & $100 \%$ \\
\hline Berlingo_8 & $50 \%$ & $50 \%$ & $100 \%$ & $100 \%$ & $100 \%$ & $50 \%$ \\
\hline Berlingo_9 & $100 \%$ & $100 \%$ & $86 \%$ & $100 \%$ & $88 \%$ & $94 \%$ \\
\hline $\begin{array}{c}\text { Berlingo_1 } \\
0\end{array}$ & $100 \%$ & $51 \%$ & $69 \%$ & $94 \%$ & $51 \%$ & $94 \%$ \\
\hline Average & $80 \%$ & $80 \%$ & $89 \%$ & $94 \%$ & $84 \%$ & $78 \%$ \\
\hline
\end{tabular}

Evaluation of the vehicles' performance during the fleet testing was very positive. The drivers did not observe a lack of power, poor acceleration of the vehicles or excessive fuel consumption. No major problems were observed with the cold start of the engine (the test was carried from August to
December), this means the end of the test took place in colder weather conditions. There were no problems with hot start of the engines. The drivers did not observe $s$ in exhaust gases smoke during acceleration or during driving with heavier load.

Table 8. Results of drivers' evaluation of Citroen Jumper performance with fueling with BIOXDIESEL (averaged)

\begin{tabular}{|c|c|c|c|c|c|c|}
\hline Vehicle & $\begin{array}{c}\text { Accelera } \\
\text {-tion }\end{array}$ & $\begin{array}{c}\text { Drive } \\
\text { with load }\end{array}$ & $\begin{array}{c}\text { Cold start } \\
\text { of the } \\
\text { engine }\end{array}$ & $\begin{array}{c}\text { Hot start of } \\
\text { the engine }\end{array}$ & Noise & Exhaust \\
\hline Jumper_1 & $100 \%$ & $100 \%$ & $29 \%$ & $85 \%$ & $71 \%$ & $81 \%$ \\
\hline Jumper_2 & $89 \%$ & $94 \%$ & $94 \%$ & $100 \%$ & $100 \%$ & $100 \%$ \\
\hline Jumper_3 & $100 \%$ & $100 \%$ & $7 \%$ & $67 \%$ & $50 \%$ & $100 \%$ \\
\hline Jumper_4 & $100 \%$ & $100 \%$ & $100 \%$ & $100 \%$ & $100 \%$ & $100 \%$ \\
\hline Jumper_5 & $94 \%$ & $86 \%$ & $77 \%$ & $89 \%$ & $78 \%$ & $83 \%$ \\
\hline Average & $\mathbf{9 7 \%}$ & $\mathbf{9 6 \%}$ & $\mathbf{6 1 \%}$ & $\mathbf{8 8 \%}$ & $\mathbf{8 0} \%$ & $\mathbf{9 3 \%}$ \\
\hline
\end{tabular}

Table 9. Comparison of fuel consumption of the selected Citroen Berlingo and Citroen Jumper before the test (standard diesel fuel) and with BIOXDIESEL fuel

\begin{tabular}{|c|c|c|c|c|c|c|}
\hline \multirow{3}{*}{ Vehicle } & \multicolumn{3}{|c|}{ Diesel fuel } & \multicolumn{3}{|c|}{ Diesel fuel } \\
\hline & \multicolumn{3}{|c|}{ August - December 2014} & \multicolumn{3}{|c|}{ February - July 2015} \\
\hline & $\begin{array}{l}\text { amout } \\
\text { of fuel } \\
{\left[\mathrm{dm}^{3}\right]}\end{array}$ & $\begin{array}{c}\text { Covered } \\
\text { distance } \\
{[\mathrm{km}]}\end{array}$ & $\begin{array}{c}\text { Fuel } \\
\text { consumption } \\
{\left[\mathrm{dm}^{3} / 100 \mathrm{~km}\right]}\end{array}$ & $\begin{array}{l}\text { amout } \\
\text { of fuel } \\
{\left[\mathrm{dm}^{3}\right]}\end{array}$ & $\begin{array}{c}\text { Covered } \\
\text { distance } \\
{[\mathrm{km}]}\end{array}$ & $\begin{array}{c}\text { Fuel } \\
\text { consumption } \\
{\left[\mathrm{dm}^{3} / 100 \mathrm{~km}\right]}\end{array}$ \\
\hline $\begin{array}{c}\text { Berlingo } \\
1\end{array}$ & 271 & 2824 & 9,6 & 124 & 1073 & 11,6 \\
\hline $\begin{array}{c}\text { Berlingo } \\
2\end{array}$ & 312 & 3531 & 8,8 & - & - & - \\
\hline Jumper 1 & 1901 & 18795 & 10,1 & 546 & 4235 & 12,9 \\
\hline Jumper 2 & 1037 & 10611 & 9,8 & 1129 & 12505 & 9,0 \\
\hline \multirow{3}{*}{ Vehicle } & \multicolumn{3}{|c|}{ BIOXDIESEL } & \multicolumn{3}{|c|}{ BIOXDIESEL } \\
\hline & \multicolumn{3}{|c|}{ August - December 2015} & \multicolumn{3}{|c|}{ February - April 2016} \\
\hline & $\begin{array}{l}\text { amout } \\
\text { of fuel } \\
{\left[\mathrm{dm}^{3}\right]} \\
\end{array}$ & $\begin{array}{c}\text { Covered } \\
\text { distance } \\
{[\mathrm{km}]} \\
\end{array}$ & $\begin{array}{c}\text { Fuel } \\
\text { consumption } \\
{\left[\mathrm{dm}^{3} / 100 \mathrm{~km}\right]}\end{array}$ & $\begin{array}{l}\text { amout } \\
\text { of fuel } \\
{\left[\mathrm{dm}^{3}\right]} \\
\end{array}$ & $\begin{array}{c}\text { Covered } \\
\text { distance } \\
{[\mathrm{km}]} \\
\end{array}$ & $\begin{array}{c}\text { Fuel } \\
\text { consumption } \\
{\left[\mathrm{dm}^{3} / 100 \mathrm{~km}\right]}\end{array}$ \\
\hline $\begin{array}{c}\text { Berlingo } \\
1\end{array}$ & 173 & 1460 & 11,9 & 175 & 1738 & 10,1 \\
\hline $\begin{array}{c}\text { Berlingo } \\
2\end{array}$ & 312 & 3503 & 8,9 & 276 & 2812 & 9,8 \\
\hline Jumper 1 & - & - & - & 389 & 3152 & 12.3 \\
\hline Jumper 2 & - & - & - & 538 & 4598 & 11.7 \\
\hline
\end{tabular}

Table 9 presents comparison of fuel consumption recorded one year before the start of the test, using standard Diesel fuel and during the test with BIOXDIESEL fuel.

\section{Summary and conclusions}

Unlike the vehicles performance measurement on the vehicle test bed or testing the engines in non-stationary conditions, the drivers did not see a drop of performance of the vehicles when fueling with the BIOXDIESEL fuel. The difference of the maximal engine power and torque did not influence the daily operation of the vehicles. No major maintenance problems were observed. It is worth to mention, that the parcel delivery vehicles are operated in difficult duty cycle: high number of start and stop of the engine per day, driving mainly in urban conditions.

It is worth to notice, that in case of the Berlingo's, the maximum power of the engines appears in lower engine speed when fueling with BIOXDIESEL in comparison with the standard diesel fuel.

Also the fuel consumption of the BIOXDIESEL fuel is not significantly different to standard Diesel fuel. 
Presented results of testing the engines fueled with the BIOXDIESEL and Diesel show:

- similar efficiency engine feeding BIOXDIESEL and Diesel,

- fuel consumption, vehicles behaviour in everyday natural operation remained the same for standard Diesel and BIOXDIESEL;

- lack of linear relations between calorific value of biofuel and the peak power of the engine related to the standard diesel fuel confirms more efficient combustion of BIOXDIESEL fuel.

Analysis of presented in this paper results of the road testing, vehicle test bed measurement, testing in nonstationary conditions and evaluation of vehicle performance by the drivers in day by day operation entitle to state, that the BIOXDIESEL fuel is very advanced, and can be used as an alternative fuel for all Diesel engines.

\section{Nomenclature}

FAEE - fatty acid ethyl esters

FAME - fatty acid methyl esters

\section{Bibliography}

[1] STRUŚ, M.S. Ocena wpływu biopaliw na wybrane właściwości eksploatacyjne silników o zapłonie samoczynnym. Oficyna Wydawnicza Politechniki Wrocławskiej, Wrocław 2012.

[2] RAMALHO, E., SANTOS, I., MAIA, A. et al. Thermal characterization of the poultry fat biodiesel, Journal of Thermal Analysis and Calorimetry. 2011, 106, 825-829.

[3] CHAKRABORTY, R., GUPTA, A.K., CHOWDHURY, R. Conversion of slaughterhouse and poultry farm animal fats and wastes to biodiesel: parametric sensitivity and fuel quality assessment, Renewable and Sustainable Energy Reviews. 2014, 29, 120-134.

Mieczysław Struś, DSc., DEng. - Faculty of Mechanical and Power Engineering, Wrocław University of Technology.

e-mail: Mieczyslaw.Strus@pwr.edu.pl

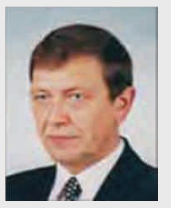

Mariusz Rewolte, MEng. - Proagroenergia Przedsiębiorstwo Innowacyjno-Wdrożeniowe sp. z o.o.

e-mail: Mariusz.Rewolte@proagroenergia.pl
[4] STRUŚ, M.S. Efektywność silników spalinowych o zapłonie samoczynnym zasilanych paliwem Bioxdiesel z komponentami całkowicie odnawialnymi. Inżynieria Maszyn. 2014, 2(19), 108-115.

[5] STRUŚ, M.S. The biofuel Bioxdiesel with ethyl components in feeding Diesel engines. Silniki Spalinowe. 2011, 3, $1-9$.

[6] STRUŚ, M.S., POPRAWSKI, W., REWOLTE, M. Efficiency of raw material selection for the second generation BIOXDIESEL biofuel for Diesel engines. Combustion Engines. 2015, 144(3), 1053-1059.

[7] STRUŚ, M.S., POPRAWSKI, W., REWOLTE, M., KARDASZ, P. Feeding the engines of fleet vehicles with BIOXDIESEL fuel and heavy alcohols. Journal of KONES. 2016 , 23(4), 495-503.

Wojciech Poprawski, DEng. - Faculty of Mechanical and Power Engineering, Wrocław University of Technology.

e-mail: Wojciech.Poprawski@pwr.edu.pl

\section{Acknowledgement}

This research has been funded under INNOTECH II Programme, project no. INNOTECH-K2/INZ/88/182607/NCBiR/13. 